\title{
Streptomyces gramineus sp. nov., an antibiotic-producing actinobacterium isolated from bamboo (Sasa borealis) rhizosphere soil
}

Correspondence

Kyung-Sook Whang

kswhang@mokwon.ac.kr
Hyo-Jin Lee, ${ }^{1}$ Song-Ih Han ${ }^{1}$ and Kyung-Sook Whang ${ }^{1,2}$

\author{
${ }^{1}$ Department of Microbial and Nano Materials, Mokwon University, Daejeon 302-729, \\ Republic of Korea \\ ${ }^{2}$ Institute of Microbial Ecology and Resources, Mokwon University, Daejeon 302-729, \\ Republic of Korea
}

The genus Streptomyces represents a group of microorganisms that are widely distributed in nature. The genus was proposed by Waksman \& Henrici (1943) for a group of aerobic, spore-forming actinobacteria, which are classified on the basis of morphological, chemotaxonomic and physiological characteristics and phylogenetic analysis. More than 500 Streptomyces species have been described, the largest number of any bacterial genus (Hain et al., 1997; Euzéby, 2009). Streptomycetes are the most prolific producers of bioactive compounds such as antibiotics (Okami \& Hotta, 1988; Berdy, 1995). Previously, we isolated 330 actinobacterial strains from bamboo forest soil and investigated their antibiotic activities against plant-pathogens such as the fungus Botrytis cinerea and the bacteria Xanthomonas campestris, Xanthomonas axonopodis pv. vesicatoria and Bacillus cereus (Lee \& Whang, 2010). Strains JR- $43^{\mathrm{T}}$ and JR-4 were isolated

The GenBank/EMBL/DDBJ accession numbers for the 16S rRNA gene sequences of strains JR-43 ${ }^{\top}$ and JR-4 are HM748598 and HM748597, respectively.

Two supplementary figures and two supplementary tables are available with the online version of this paper. from a soil sample taken from Damyang, Jeonnam, South Korea, after 1 week of incubation at $28{ }^{\circ} \mathrm{C}$ on inorganic saltsstarch agar [International Streptomyces Project (ISP) medium 4; Shirling \& Gottlieb, 1966]. The isolates were stored at $-86{ }^{\circ} \mathrm{C}$ in the presence of $20 \%(\mathrm{v} / \mathrm{v})$ glycerol.

Physiological media were prepared according to the methods of the ISP (Shirling \& Gottlieb, 1966). Czapek's agar was prepared according to Waksman (1961). Morphological and physiological characteristics were determined as recommended by Williams et al. (1989) and morphological observations of spores and mycelium were conducted using light microscopy and scanning electron microscopy. The strains were Gram-positive with the staining procedure of Gerhardt et al. (1994). Physiological tests were carried out at $28{ }^{\circ} \mathrm{C}$ unless otherwise indicated. D-Glucose, D-fructose, Larabinose, inositol, D-mannitol, raffinose, L-rhamnose, sucrose and D-xylose were tested as sole carbon sources at concentrations of $1 \%(\mathrm{w} / \mathrm{v})$ after filter sterilization. Growth on ISP 4 at $4,10,15,20,25,30$ and $37^{\circ} \mathrm{C}$, at pH 4-12 (at intervals of $1 \mathrm{pH}$ unit) and with $0,0.1,0.5,1,2$ and $3 \%(\mathrm{w} / \mathrm{v}) \mathrm{NaCl}$ was examined in inorganic salts-starch broth after 21 days. 
The 16S rRNA gene was amplified using the universal primers 27F [5'-AGAGTTTGATC(AC)TGGCTCAG-3'] and 1492R [5'-ACGG(CT)TACCTTGTTACGACTT-3'] (Weisburg et al., 1991) and nucleotide sequences were determined with an automated sequencer (model 377; Applied Biosystems). The 16S rRNA gene sequences of strains JR- $43^{\mathrm{T}}$ and JR-4 (1422 nt) were compared with corresponding sequences of representative reference strains of the genus Streptomyces. Identification of the closest phylogenetic neighbours and calculation of pairwise $16 \mathrm{~S}$ rRNA gene sequence similarities were achieved using the EzTaxon server (http://www.eztaxon. org/; Chun et al., 2007). Phylogenetic trees were generated using the neighbour-joining (Saitou \& Nei, 1987), maximum-parsimony (Fitch, 1971) and maximum-likelihood (Felsenstein, 1981) algorithms in the PHYLIP package (Felsenstein, 2005). Sequence distances were calculated using the F84 model (Felsenstein, 1984). A bootstrap analysis to evaluate the stability of the trees was performed using a consensus tree based on 1000 randomly generated trees. To determine genomic relatedness, DNA-DNA hybridization was performed using the modified method of Ezaki et al. (1989).

Cellular fatty acids of cells grown in tryptic soy broth (Difco) for 5 days at $28{ }^{\circ} \mathrm{C}$ were prepared, separated and identified according to the instructions for the Microbial Identification System (Microbial ID) using the Microbial Identification software package and the TSBA 40 database version 4.0 (Sasser, 1990). For chemotaxonomic analysis, freeze-dried cells were obtained from cultures grown in inorganic salts-starch broth in a shaking incubator at 120 r.p.m. and $28{ }^{\circ} \mathrm{C}$ for 14 days. Menaquinones were extracted and purified according to Collins (1985) and analysed by HPLC. The isomer of diaminopimelic acid in the cell wall and the whole-cell sugars were analysed as described by Lechevalier \& Lechevalier $(1970,1980)$ and Staneck \& Roberts (1974), respectively. Polar lipids were extracted and detected by the method of Minnikin et al. (1984). Cell biomass for DNA extraction was obtained after growth in tryptic soy broth at $28{ }^{\circ} \mathrm{C}$ for 5 days. Chromosomal DNA was isolated by the method of Saito \& Miura (1963) and the G+C content was determined by HPLC, as described by Mesbah et al. (1989).

Strains JR- $43^{\mathrm{T}}$ and JR-4 grew well on various media, such as yeast extract-malt extract agar (ISP 2), oatmeal agar (ISP 3), inorganic salts-starch agar (ISP 4), glycerol-asparagine agar (ISP 5), peptone-yeast extract-iron agar (ISP 6), tyrosine agar (ISP 7), nutrient agar and Czapek's agar. Grey aerial mycelium formed on ISP 2 and 4. Aerial mycelium did not form on ISP 6 or nutrient agar. Different diffusible pigments were produced on different media and melanin was produced on ISP 6 (Table S1, available in IJSEM Online). The isolates produced rectiflexibiles spore chains with spinysurfaced spores (Fig. S1) and degraded cellulose, gelatin, starch and casein and utilized D-fructose, D-glucose, inositol, D-mannitol, raffinose, L-rhamnose, sucrose and D-xylose (Table 1). The predominant menaquinones were MK-9 $\left(\mathrm{H}_{8}\right)$ and MK-9 $\left(\mathrm{H}_{6}\right)$. The polar lipid pattern consisted of phosphatidylethanolamine, hydroxyphosphatidylethanolamine,

Table 1. Some characteristics that differentiate strains $J R-43^{\top}$ and $J R-4$ from closely related members of the genus Streptomyces

Strains: 1, Streptomyces gramineus sp. nov. JR-43 ${ }^{\mathrm{T}} ; 2$, S. gramineus sp. nov. JR-4; 3, S. recifensis NBRC $12813^{\mathrm{T}}$; 4, S. seoulensis NBRC $16668^{\mathrm{T}}$. Data were taken from this study. All strains have grey aerial mycelium on ISP 4 and rectiflexibiles spore chain morphology and are positive for degradation of cellulose and casein and utilization of D-glucose, D-mannitol, raffinose, sucrose and D-xylose. +, Positive; w, weakly positive; -, negative.

\begin{tabular}{|lcccc|}
\hline Characteristic & $\mathbf{1}$ & $\mathbf{2}$ & $\mathbf{3}$ & $\mathbf{4}$ \\
\hline Substrate mycelium colour (ISP 4)* & I & I & WH & I \\
Spore ornamentation $\dagger$ & SP & SP & SM & SM \\
Melanin production (ISP 6) & + & + & - & - \\
Soluble pigments & + & + & - & - \\
Degradation of: & & & & \\
$\quad$ Gelatin & + & + & - & + \\
Starch & + & + & - & + \\
Maximum NaCl concentration for growth (\%, w/v) & 3 & 3 & 1 & 2 \\
Growth at 37 C & + & + & - & + \\
pH range for growth & $4-8$ & $4-9$ & $4-8$ & $4-8$ \\
Utilization of: & & & & \\
L-Arabinose & - & - & + & - \\
D-Fructose & + & W & + & + \\
Inositol & + & + & - & - \\
L-Rhamnose & + & + & - & + \\
\hline
\end{tabular}

${ }^{*}$, Ivory; wH, white.

$\dagger$ SM, Smooth; sP, spiny. 


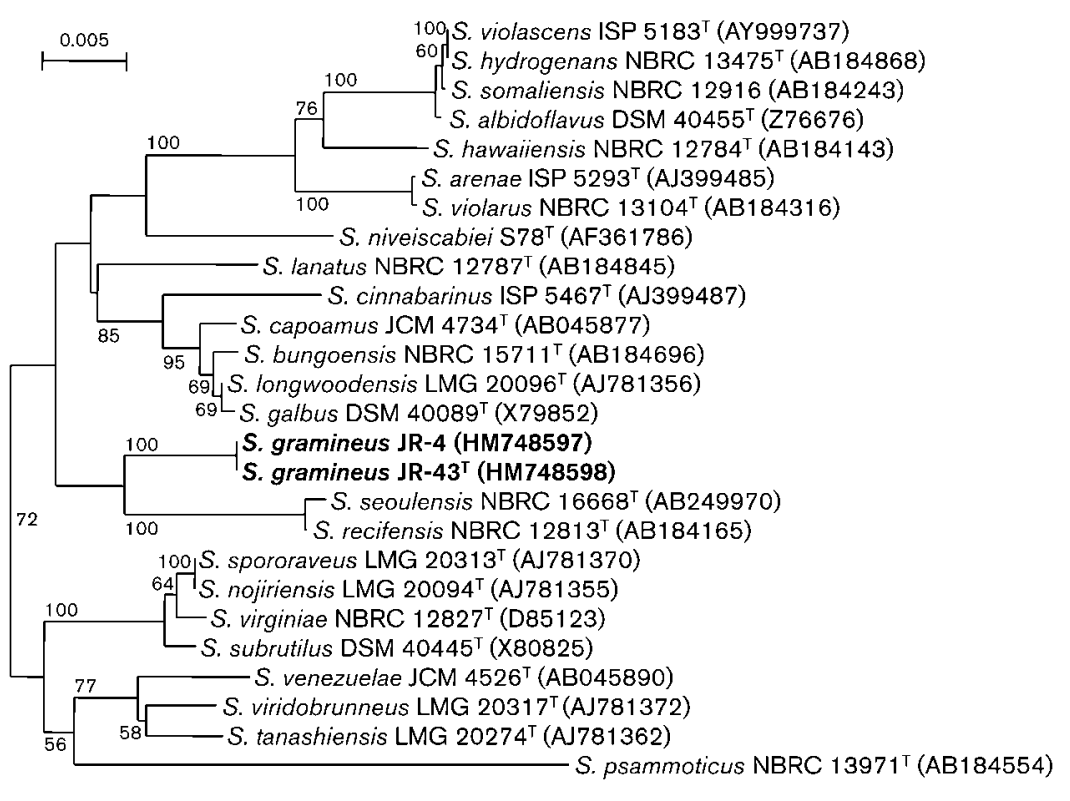

Fig. 1. Consensus phylogenetic tree based on 16S rRNA gene sequences showing the positions of strains JR- $43^{T}$ and JR-4 among their phylogenetic neighbours. Bootstrap values (>50\%) based on 1000 replicates are shown at branch nodes. Bar, 0.005 substitutions per nucleotide position. phosphatidylcholine, phosphatidylinositol and phosphatidylinositol mannoside (Fig. S2). The major cellular fatty acids were iso- $\mathrm{C}_{16: 0}$, iso- $\mathrm{C}_{14: 0}$ anteiso- $\mathrm{C}_{15: 0}$ and iso- $\mathrm{C}_{15: 0}$ (Table S2). The cell-wall peptidoglycan contained LL- and meso-diaminopimelic acid and glutamic acid, alanine and glycine. Whole-cell hydrolysates contained predominantly glucose. The DNA G + C content of strains JR $-43^{\mathrm{T}}$ and JR-4 was 70.5 and $69.2 \mathrm{~mol} \%$, respectively.

The 16S rRNA gene sequence analysis showed that strains JR $-43^{\mathrm{T}}$ and JR-4 were most closely related to Streptomyces seoulensis NBRC $16668^{\mathrm{T}}$ and Streptomyces recifensis NBRC $12813^{\mathrm{T}}$ (both $98.2 \% 16 \mathrm{~S}$ rRNA gene sequence similarity). In the phylogenetic tree (Fig. 1), the isolates formed a welldefined lineage in a cluster containing $S$. seoulensis NBRC $16668^{\mathrm{T}}$ and S. recifensis NBRC $12813^{\mathrm{T}}$. The isolates exhibited high DNA-DNA relatedness with each other $(87.5 \pm 3.3 \%)$ and low DNA-DNA relatedness with $S$. recifensis NBRC $12813^{\mathrm{T}}(31.42-37.87 \pm 0.7-2.2 \%)$ and $S$. seoulensis NBRC $16668^{\mathrm{T}}(32.34-42.92 \pm 1.5-2.9 \%)$.

It is concluded from the above results that strains JR- $43^{\mathrm{T}}$ and JR-4 should be recognized as members of a novel species of the genus Streptomyces.

\section{Description of Streptomyces gramineus sp. nov.}

Streptomyces gramineus (gra.mi.ne' us. L. masc. adj. gramineus of grass, referring to bamboo as the first isolation source).

Aerobic, Gram-stain-positive actinobacterium that forms extensively branched substrate mycelium and aerial hyphae that differentiate into rectiflexibiles chains of spiny-surfaced spores. Growth occurs at $4-37{ }^{\circ} \mathrm{C}$, at $\mathrm{pH} 4-8$ and with $3 \%$ $(\mathrm{w} / \mathrm{v}) \mathrm{NaCl}$. Good growth occurs on all tested ISP media (2, $3,4,5,6,7)$, Czapek's agar and nutrient agar at $28{ }^{\circ} \mathrm{C}$. Shows antibacterial activities against Xanthomonas campestris LMG
$568^{\mathrm{T}}$ and Xanthomonas axonopodis pv. vesicatoria LMG 905. The aerial mycelium is grey and the substrate mycelium is ivory on ISP 4. Melanin pigment is formed on peptone-yeast extract iron agar (ISP 6). Degrades casein, cellulose, gelatin and starch. Utilizes several compounds as sole carbon sources including D-fructose, D-glucose, inositol, D-mannitol, raffinose, L-rhamnose, sucrose and D-xylose. The cellwall peptidoglycan contains LL- and meso-diaminopimelic acid and glutamic acid, alanine and glycine. Whole-cell hydrolysates mainly contain glucose. The predominant menaquinones are MK- $9\left(\mathrm{H}_{6}\right)$ and MK- $9\left(\mathrm{H}_{8}\right)$. The polar lipid pattern consists of phosphatidylethanolamine, hydroxyphosphatidylethanolamine, phosphatidylcholine, phosphatidylinositol and phosphatidylinositol mannoside. The fatty acids are iso- $\mathrm{C}_{16: 0}$, iso- $\mathrm{C}_{14: 0}$, anteiso- $\mathrm{C}_{15: 0}$, iso- $\mathrm{C}_{15: 0}$, iso- $\mathrm{C}_{17: 0}, \mathrm{C}_{16: 0}$, anteiso- $\mathrm{C}_{17: 0}$, iso- $\mathrm{C}_{17: 1} \omega 9 c$ and iso- $\mathrm{C}_{16: 1}$ $\mathrm{H}$. The DNA G $+\mathrm{C}$ content is $69-71 \mathrm{~mol} \%$.

The type strain, JR- $43^{\mathrm{T}}\left(=\right.$ KACC $\left.15079^{\mathrm{T}}=\mathrm{NBRC} 107863^{\mathrm{T}}\right)$, was isolated from bamboo (Sasa borealis) rhizosphere soil, collected from Damyang, Jeonnam, South Korea.

\section{Acknowledgements}

This research was supported financially by the Ministry of Education, Science Technology (MEST) and the Korea Institute for Advancement of Technology (KIAT) through the Human Resource Training Project for Regional Innovation (M-02-20080704171810).

\section{References}

Berdy, J. (1995). Are actinomycetes exhausted as a source of secondary metabolites? Biotechnologia 7-8, 13-34.

Chun, J., Lee, J. H., Jung, Y., Kim, M., Kim, S., Kim, B. K. \& Lim, Y. W. (2007). EzTaxon: a web-based tool for the identification of prokaryotes based on $16 \mathrm{~S}$ ribosomal RNA gene sequences. Int J Syst Evol Microbiol 57, 2259-2261. 
Collins, M. D. (1985). Isoprenoid quinone analysis in classification and identification. In Chemical Methods in Bacterial Systematics, pp. 267-287. Edited by M. Goodfellow \& D. E. Minnikin. London: Academic Press.

Euzéby, J. P. (2009). List of Prokaryotic Names with Standing in Nomenclature. http://www.bacterio.cict.fr/

Ezaki, T., Hashimoto, Y. \& Yabuuchi, E. (1989). Fluorometric deoxyribonucleic acid-deoxyribonucleic acid hybridization in microdilution wells as an alternative to membrane filter hybridization in which radioisotopes are used to determine genetic relatedness among bacterial strains. Int J Syst Bacteriol 39, 224-229.

Felsenstein, J. (1981). Evolutionary trees from DNA sequences: a maximum likelihood approach. J Mol Evol 17, 368-376.

Felsenstein, J. (1984). Distance methods for inferring phylogenies: a justification. Evolution 38, 16-24.

Felsenstein, J. (2005). PHYLIP (phylogeny inference package), version 3.65. Distributed by the author. Department of Genome Sciences, University of Washington, Seattle, USA.

Fitch, W. M. (1971). Toward defining the course of evolution: minimum change for a specific tree topology. Syst Zool 20, 406-416.

Gerhardt, P., Murray, R. G. E., Wood, W. A. \& Krieg, N. R. (editors) (1994). Methods for General and Molecular Bacteriology. Washington, DC: American Society for Microbiology.

Hain, T., Ward-Rainey, N., Kroppenstedt, R. M., Stackebrandt, E. \& Rainey, F. A. (1997). Discrimination of Streptomyces albidoflavus strains based on the size and number of 16S-23S ribosomal DNA intergenic spacers. Int J Syst Bacteriol 47, 202-206.

Lechevalier, M. P. \& Lechevalier, H. A. (1970). Chemical composition as a criterion in the classification of aerobic actinomycetes. Int J Syst Bacteriol 20, 435-443.

Lechevalier, M. P. \& Lechevalier, H. A. (1980). The chemotaxonomy of actinomycetes. In Actinomycete Taxonomy (Special Publication no. 6), pp. 227-291. Edited by A. Dietz \& J. Thayer. Arlington, VA: Society for Industrial Microbiology.

Lee, H. J. \& Whang, K. S. (2010). Biodiversity and phylogenetic analysis of Streptomyces collected from bamboo forest soil. Kor J Microbiol 46, 262-269.
Mesbah, M., Premachandran, U. \& Whitman, W. B. (1989). Precise measurement of the $\mathrm{G}+\mathrm{C}$ content of deoxyribonucleic acid by high-performance liquid chromatography. Int J Syst Bacteriol 39, 159-167.

Minnikin, D. E., O’Donnell, A. G., Goodfellow, M., Alderson, G., Athalye, G., Schaa, A. \& Parlett, J. H. (1984). An integrated procedure for the extraction of bacterial isoprenoid quinones and polar lipids. J Microbiol Methods 2, 233-241.

Okami, Y. \& Hotta, A. K. (1988). Search and discovery of new antibiotics. In Actinomycetes in Biotechnology, pp. 33-67. Edited by M. Goodfellow, S. T. Williams \& M. Mordarski. London: Academic Press.

Saito, H. \& Miura, K. I. (1963). Preparation of transforming deoxyribonucleic acid by phenol treatment. Biochim Biophys Acta 72, 619-629.

Saitou, N. \& Nei, M. (1987). The neighbor-joining method: a new method for reconstructing phylogenetic trees. Mol Biol Evol 4, 406425.

Sasser, M. (1990). Identification of bacteria by gas chromatography of cellular fatty acids, MIDI Technical Note 101. Newark, DE: MIDI Inc.

Shirling, E. B. \& Gottlieb, D. (1966). Methods for characterization of Streptomyces species. Int J Syst Bacteriol 16, 313-340.

Staneck, J. L. \& Roberts, G. D. (1974). Simplified approach to identification of aerobic actinomycetes by thin-layer chromatography. Appl Microbiol 28, 226-231.

Waksman, S. A. (1961). The Actinomycetes. Classification, Identification and Descriptions of Genera and Species, vol. 2. Baltimore: Williams \& Wilkins.

Waksman, S. A. \& Henrici, A. T. (1943). The nomenclature and classification of the actinomycetes. J Bacteriol 46, 337-341.

Weisburg, W. G., Barns, S. M., Pelletier, D. A. \& Lane, D. J. (1991). $16 \mathrm{~S}$ ribosomal DNA amplification for phylogenetic study. J Bacteriol 173, 697-703.

Williams, S. T., Goodfellow, M. \& Alderson, G. (1989). Genus Streptomyces Waksman and Henrici 1943, 339 ${ }^{\mathrm{AL}}$. In Bergey's Manual of Systematic Bacteriology, vol. 4, pp. 2452-2492. Edited by S. T. Williams, M. E. Sharpe \& J. G. Holt. Baltimore: Williams \& Wilkins. 